\title{
Trump claims public health warnings on covid-19 are a conspiracy against him
}

\author{
Owen Dyer
}

Montreal

US public health officials are struggling to overcome conflicting messaging on covid-19 from the White House, as Donald Trump seems to want to downplay the threat, hoping to minimise economic disruption that could harm his chances of re-election in November.

The virus seized Trump's attention on his 26 February return from India, as he watched on the screens of Air Force One the first stock market plunge driven by pandemic fears. He took to Twitter to complain that "Low Ratings Fake News . . . are doing everything possible to make the Caronavirus [sic] look as bad as possible, including panicking markets, if possible."

The president was particularly incensed about an infectious disease expert at the Centers for Disease Control and Prevention (CDC), Nancy Messonnier, whom he blamed for triggering the market slide by announcing that community spread was ultimately inevitable in the US. That night, the talk radio host Rush Limbaugh denounced Messonnier on his show, noting that her brother was Rod Rosenstein, a former justice department official who appointed Robert Mueller to investigate Russian assistance to Trump's election campaign.

Trump was later asked at a press conference if he agreed with Limbaugh that CDC was "exaggerating the threat of coronavirus" to "weaponise" it and "hurt you politically." He replied, "I think they are. And I'd like it to stop."

Hours later, Trump banned all federal health officials from speaking to the public without express permission from the office of the vice president, Mike Pence.

On 4 March Trump suggested on Fox News that going to work when infected with covid-19 was commonplace. "You have thousands or even hundreds of thousands of people that get better, just by sitting around-and even going to work. Some of them go to work. But they get better," he told host Sean Hannity.

Trump argued that thousands of mild cases were being missed. The World Health Organization's figure of $3.4 \%$ of cases resulting in death did not represent the true proportion, which his "hunch" suggested was probably under $1 \%$, he told Hannity. In fact the WHO had itself explained that the figure describes deaths as a proportion of reported cases only and is not an estimated case fatality rate.

Trump's perception of the virus as a political threat has only deepened as headlines piled up listing the public health agencies and programmes that he had defunded. Other media reports recounted his administration's early missteps, included the failed quarantine of a cruise ship and the repatriation of infected Americans from Wuhan alongside healthy people, to be met on landing by unprotected government workers. ${ }^{1}$

The CDC drew particular criticism for rejecting WHO's covid-19 test kit, only to make a faulty one itself. Tests remain in very short supply, and the US has tested far fewer people than other affected countries. "We're weeks behind because we had this problem," Scott Becker, chief executive officer of the Association of Public Health Laboratories, told ProPublica. ${ }^{2}$ The number of US deaths now stands at 12. Eleven were in Washington state, where health officials believe the virus circulated for weeks before being detected.

The disease has exposed shortcomings in the US health system and economy. Millions of workers have no paid sick leave, and the question of uninsured citizens looms large.

The secretary of health and human services, Alex Azar, struck a jarring early note when he refused to promise a congressional hearing that a future vaccine would be affordable. "We can't control that price because we need the private sector to invest," he argued. After a fierce backlash, he reversed course, promising that the government would cover vaccine costs. The government is now also in discussions about assuming treatment costs for uninsured people.

At a televised White House conference with vaccine makers, Trump struggled to understand their repeated explanations that no vaccine could be ready for public use in less than a year to 18 months.

He was corrected several times, but at the end of the conference he again wrongly told reporters, "I've heard very quick numbers-a matter of months-and I've heard pretty much a year would be an outside number."

Anthony Fauci, director of the National Institute of Allergy and Infectious Diseases, who was next to Trump, interjected: "Would you make sure you get the president the information that a vaccine that you make and start testing in a year is not a vaccine that's deployable."

Fauci later told Politico: "You don't want to go to war with a president. But you've got to walk the fine balance of making sure you continue to tell the truth." 
2 Chen C, Allen M, Churchill L, Arnsdorf I. Key missteps at the CDC have set back its ability to detect the potential spread of Coronavirus. ProPublica. Feb 2020. https://www. propublica.org/article/cdc-coronavirus-covid-19-test.
Published by the BMJ Publishing Group Limited. For permission to use (where not already granted under a licence) please go to http://group.bmj.com/group/rights-licensing/ permissions 